\title{
Enzyme Immobilization in Polymerized lonic Liquids-based Hydrogels for Active and Reusable Biocatalysts
}

\author{
A. Grollmischa \\ U. Kragla \\ J. Großeheilmann ${ }^{* b, c}$ \\ a Department of Chemistry, University of Rostock, Albert-Einstein- \\ Str. 3a, D-18059 Rostock, Germany \\ b Institute for Chemical and Thermal Process Engineering, TU \\ Braunschweig, Langer Kamp 7, D-38106 Braunschweig, Germany \\ c Center of Pharmaceutical Engineering (PVZ), TU Braunschweig, \\ Franz-Liszt-Straße 35a, D-38106 Braunschweig, Germany \\ j.grosseheilmann@tu-braunschweig.de
}

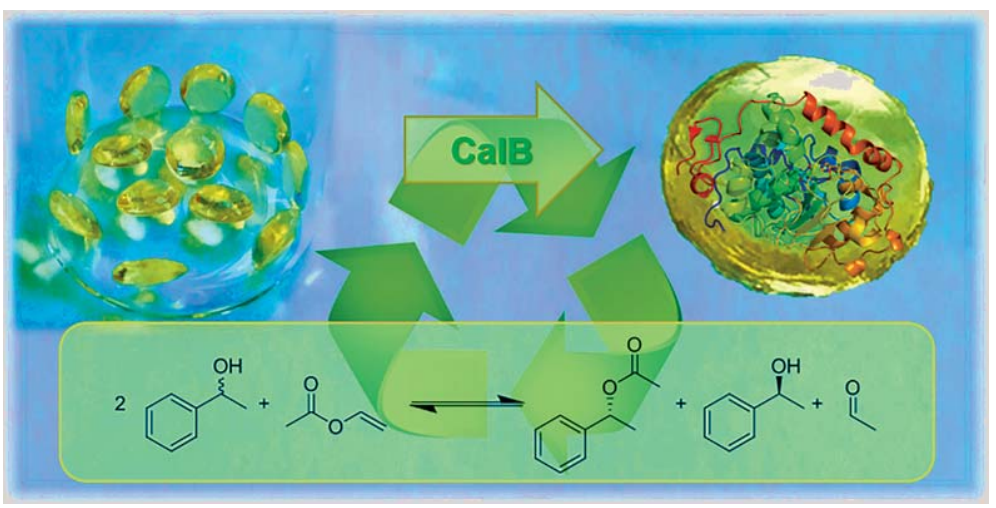

Received: 22.04.2018

Accepted after revision: 23.04.2018

Published online: 08.06 .2018

DOI: 10.1055/s-0037-1610144; Art ID: so-2018-d0265-op

License terms: cc)

Abstract Enzyme immobilization in polymerized ionic liquids (PILs) promises to be a versatile tool for simple recovery and reuse of catalysts. In this study, a raw extract of CalB was encapsulated in poly(VElm$\mathrm{Br}$ ) and assessed with respect to solvent, temperature, amount of enzyme, leaching behavior, and reusability on the example of the kinetic resolution of rac-1-phenylethanol with vinyl acetate. This immobilization method increased the enzyme activity of the CalB raw extract in comparison to the non-immobilized enzyme. The desired product was synthesized with high enantiomeric excess (ee) and no leaching of active enzyme was observed in the experiments. The immobilization method was compared to Novozyme 435 and Lipozyme RM IM, as commercially available immobilisates. Nonpolar solvents, including $n$-heptane and $n$-dodecane, proved to be the best reaction solvents, showing nearly full conversion and high catalytic activities. The encapsulated lipase was easily recovered from the reaction mixture and reused for ten cycles.

Key words immobilization, enzyme, lipase, ionic liquid, recycling

The majority of biocatalytic industrial processes operate with heterogeneous catalysts, using immobilized enzymes that are easily removed from the process stream. ${ }^{1}$ Immobilization is regarded as the key enabling technology for enhancing handling and stability of the enzymes. Other advantages include an easier reactor operation, simple product separation, application in continuous processes, and a wider reactor choice. In terms of 'green' and 'sustainable' chemistry, complete recovery of the enzyme and a pure product uncontaminated with protein reduce possible allergenicity. ${ }^{2-4}$ These reasons account for the increasing importance of immobilization, for which several methods are already known, including immobilizing biocatalysts on solid supports or in synthetic or natural polymers by covalent attachment, adsorption, and physical entrapment., ${ }^{5,6}$ One carrier-free immobilization technique involves crosslinking of enzymes, which, with the help of their superficial amino groups, are connected to each other by a bifunctional reagent, commonly glutaraldehyde. ${ }^{6}$ Generally, two procedures for this process are known. First, to form insoluble crosslinked enzyme crystals (CLECs), the enzyme must crystallize from an aqueous buffer before the crosslinker is added. ${ }^{4}$ The second method is much easier because it replaces crystallization with precipitation. Salts (e.g., ammonium sulfate) or water-miscible organic solvents are added to an aqueous enzyme solution. After the crosslinker is added, the crosslinked enzyme aggregates (CLEAs) precipitate. Thereafter, no purification is necessary, and the enzyme can be employed immediately. ${ }^{7}$ However, immobilization via crosslinking has several drawbacks, including low activity, poor reproducibility, and low mechanical stability, ${ }^{8}$ the latter of which can be improved by entrapping enzymes into a solid support. Apart from the traditional carriers, which include polysaccharides, synthetic resins, and zeolites, polymer networks are also used to entrap biocatalysts. ${ }^{3,9}$ However, entrapping enzymes into a solid support often results in decreased activity and increased leaching behavior due to the structure of the supporting polymers., ${ }^{3,6}$ To overcome this disadvantage, novel immobilization methods and novel polymeric materials have been investigated and reported in the literature. ${ }^{10}$ In particular, incorporating enzymes into polymer frameworks based on ionic liquids (ILs) has sparked significant interest. Polymerized ILs, also called 'polyionic liquids', are a sub-class of polyelectrolytes that have attracted increasing interest. ${ }^{11}$ PILs are usually prepared by polymerizing IL monomers; as a result, they combine the advantages of ILs (e.g., ionic conductivity, thermal, and chemical stability, tunable solution properties) and the properties of polymers, and polymerized ILs have potential applications in catalysis, energy, the environment, 
and materials science. ${ }^{12}$ For example, Goto et al. encapsulated horseradish peroxidase in PIL microparticles (pIL-MP), which were prepared by polymerizing an IL-monomer in a concentrated water-in-oil emulsion..$^{13}$ The enzyme encapsulated in pIL-MP was chemically modified with comb shaped polyethylene glycol-grafted (PEG) molecules and showed more than twice the activity of the enzyme encapsulated in a polyacrylamide microparticle. In addition, they showed enzyme solubility without loss of catalytic activity by forming aqueous microemulsion droplets in a hydrophobic IL. ${ }^{14}$ Three years later, the same research group reported the encapsulation of Candida rugosa lipase in surfactant aggregates formed in a PILs-monomer $\left([\mathrm{VEIm}]\left[\mathrm{Tf}_{2} \mathrm{~N}\right]\right) .{ }^{15}$ The encapsulated lipase remained active and exhibited excellent stability after five reaction cycles for the lipase-catalyzed hydrolysis of $p$-nitrophenyl butyrate. In 2006, poly(VEImBr) was used to immobilize glucose oxidase, which resulted in microparticles that were used as biosensors to quantify glucose in human serum samples. ${ }^{16}$ In electrochemical applications, Zhang et al. synthesized a PILs-functionalized graphene nanocomposite to immobilize glucose oxidase. ${ }^{17}$

The present study investigates the use of PILs-based hydrogels to support immobilizing lipases. Our group has recently reported successfully entrapping quinine-based organocatalysts in PILs-based hydrogels. ${ }^{18}$ Controlling the water content in the hydrogels significantly reduced catalyst leaching $(<0.01 \%)$. Previous research has described in detail the synthesis of these very interesting materials, and they have been characterized as being extremely flexible and stable against various organic solvents. ${ }^{19}$

PILs-based hydrogels provide a good environment for lipases due to their high chemical stability and adjustable water content for folding the protein, which is responsible for its activity and selectivity. The applied lipases, the monomer vinyl-imidazolium-based IL (1-vinyl-3-ethylimidazolium bromide; VEImBr), crosslinker $N, N^{\prime}$-methylenbisacrylamide, initiator ammonium peroxydisulfate (APS), and $N, N, N, N$-tetramethylethylenediamine (TEMED) yielded the enzyme-encapsulated PILs-network using a radical polymerization (Scheme 1). Gelation time and gel consistency depend on which lipase is used and how much of it is incorporated. Generally, the gelation process was complete and transparent gels formed after 10 to $120 \mathrm{~min}$. Unless otherwise noted, the hydrogels were air-dried for one day. The encapsulated enzyme provided a robust biocatalyst due to the great advantages of the PILs-based framework, including its enhanced mechanical stability, processability, flexibility, and durability.

A simple kinetic resolution reaction of rac-1-phenylethanol $\mathbf{1}$ by transesterification with vinyl acetate $\mathbf{2}$ was used as a test system (Scheme 2 ). This is catalyzed by lipases that preferentially transesterify $(R)$-1-phenylethanol, yielding the desired $(R)$-product according to Kazlauskas' rule. ${ }^{20}$ The $(S)$-enantiomer remains unchanged.

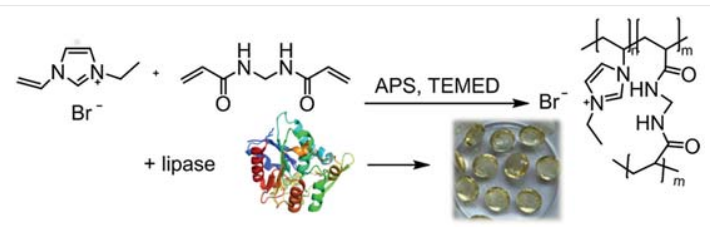

Scheme 1 Preparing encapsulated lipase in PIL-based hydrogels; radical polymerization of an imidazolium-based IL bearing a vinyl group, [VEIm] [Br] - 1-vinyl-3-ethylimidazolium bromide, and cross-linker $N, N^{\prime}$ methylenebisacrylamide (BisA). APS - Ammonium peroxydisulfate,

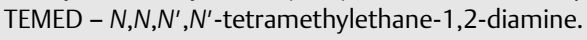

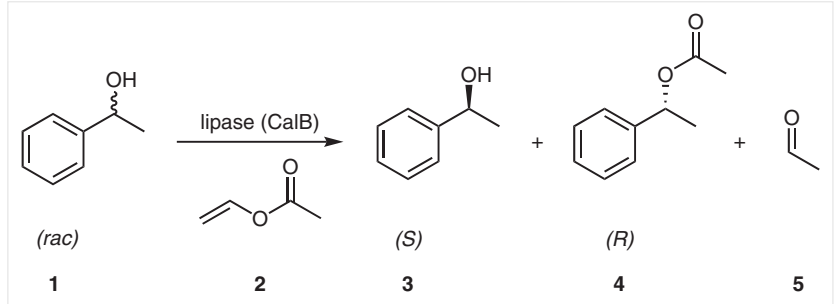

Scheme 2 Lipase-catalyzed kinetic resolution of 1-phenylethanol by transesterification

The first screening tests used Lipase B from Candida antarctica. This enzyme has been proven to be a robust protein that is stable over a wide temperature range up to $50-60{ }^{\circ} \mathrm{C} .{ }^{21}$ Initially, various common solvents were tested under the same reaction conditions for both the hydrogelimmobilized lipase and the non-immobilized lipase. In contrast, the use of pure hydrogel without encapsulated enzyme showed no catalytic influence on the reaction. Figure 1 shows the conversions for the test system after $5 \mathrm{~h}$ of reaction time. For both the immobilized and non-immobilized lipase, the best results were achieved in less polar solvents, including hexane, heptane or dodecane. Generally, the non-immobilized enzyme achieved higher conversions of up to $22 \%$, except in dodecane. Conversion was increased by $2.5 \%$ by applying hydrogel-immobilized enzyme. More polar solvents, including methyl tert-butyl ether (MTBE) and dichloromethane, showed rather poor results: approximately $1 \%$ for the non-immobilized enzyme and $<1 \%$ for the hydrogel-immobilized enzyme. This differed from results in the literature, which show that CalB achieved good conversions using MTBE as a reaction solvent. ${ }^{22}$ However, even a prolonged reaction time of $49 \mathrm{~h}$ did not enhance the conversion of the non-immobilized CalB in MTBE beyond $2 \%$. In addition, the present study investigated a possible relationship between the water activity in each reaction solution and the determined conversion but found no correlation (see the Supporting Information S1). Nevertheless, there was a clear correlation between the log of their octanol-water partition coefficient $(\log \mathrm{P})$ and the conversion. Increasing the hydrophobicity of the solvent increased the conver- 
sion from $0.3 \%$ for MTBE $(\log \mathrm{P}=0.94)$ to $24.6 \%$ for dodecane $(\log \mathrm{P}=6.1)$. Therefore, in the present study, we subsequently used heptane and dodecane exclusively.

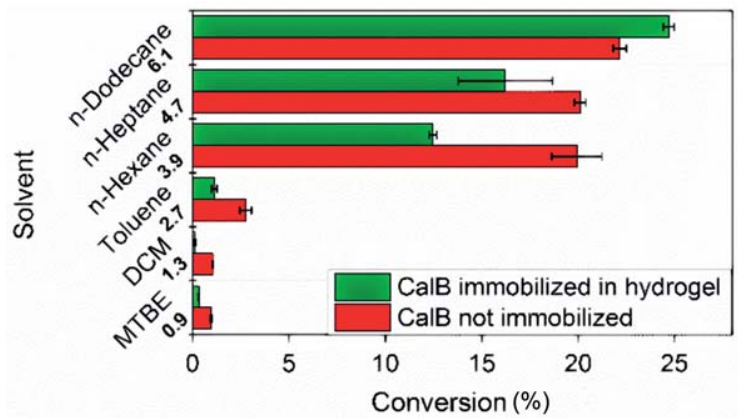

Figure 1 Results of solvent screening for the test reaction with CalB immobilized in hydrogel (green bar) and non-immobilized (red bar). The number in bold font is the predicted $\log K_{\text {ow }}$. Conditions: $20 \mathrm{~mL}$ solvent, $10 \mathrm{mM}$ rac-1-phenylethanol, $100 \mathrm{mM}$ vinyl acetate, $200 \mu \mathrm{L} \mathrm{CalB}$ either non-immobilized or immobilized in hydrogel, $40{ }^{\circ} \mathrm{C}, 5 \mathrm{~h}$, measured twice.

For both immobilized and non-immobilized enzymes, we performed a temperature screening at temperatures from $25^{\circ} \mathrm{C}$ to $55^{\circ} \mathrm{C}$ in both dodecane and heptane (Figure 2 ). A typical temperature curve showed an apparent maximum of $40{ }^{\circ} \mathrm{C}$ for both the immobilized and non-immobilized CalB. Generally, the conversion decreased at higher temperatures due to the inactivation of the enzyme during the chosen reaction time. The results of the reactions in dodecane showed that hydrogel-immobilized CalB generally achieved higher conversions than non-immobilized CalB. This can be explained by the positive interactions between the hydrogel and the enzyme, especially the imidazolium cation and the active site of the lipase. The literature describes similar negative or positive effects on CalB activity caused by imidazolium cations. ${ }^{23,24}$ Yingling et al. noted that the cation probably affected the conformation and dynamics of the CalB, influencing the size of the catalytic cavity. They further emphasized that they found no correlation between the reaction rate and the length of the cation chain or other properties of the cation. ${ }^{23}$

The screening results show two temperature maxima, $25{ }^{\circ} \mathrm{C}$ and $40{ }^{\circ} \mathrm{C}$ for the hydrogel-immobilized CalB in dodecane. The non-immobilized enzyme achieved the best results between $25^{\circ} \mathrm{C}$ and $40{ }^{\circ} \mathrm{C}$ for dodecane and between $35^{\circ} \mathrm{C}$ and $45^{\circ} \mathrm{C}$ for heptane. In all cases, conversions decreased at higher temperatures. Further experiments were performed in dodecane by varying the amount of enzyme at $40^{\circ} \mathrm{C}$. No significant increase of conversion was observed with enzyme amounts of $200 \mu \mathrm{L}$ and $400 \mu \mathrm{L}$ (see the Supporting Information S2). The best reaction conditions for further experiments were identified as $200 \mu \mathrm{L}$ of enzyme, dodecane as reaction solvent, and $40{ }^{\circ} \mathrm{C}$ as the reaction temperature. Despite incomplete conversion, a reaction

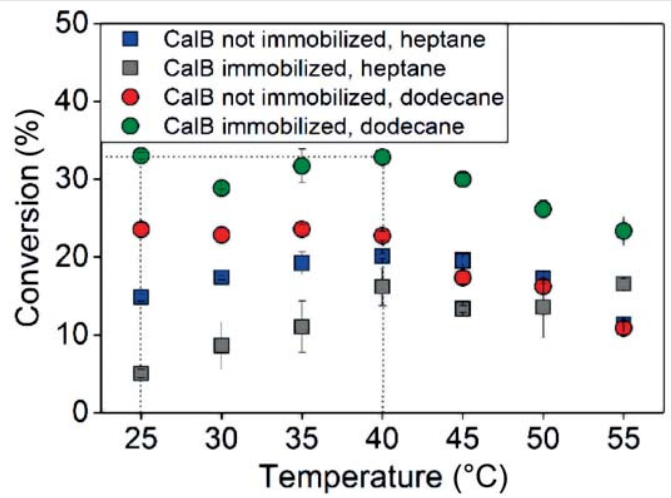

Figure 2 Results of temperature screening in dodecane (circle) and in heptane (square) for immobilized and non-immobilized enzyme. Conditions: $20 \mathrm{~mL}$ solvent, $10 \mathrm{mM}$ rac-1-phenylethanol, $100 \mathrm{mM}$ vinyl acetate, $200 \mu \mathrm{L} \mathrm{CalB}, 5 \mathrm{~h}$, measured twice.

time of $5 \mathrm{~h}$ was defined for the subsequent screening experiments, which were conducted to identify the most important differences between various lipases (immobilized or non-immobilized).

Furthermore, to classify the results for the non-immobilized enzymes, the reaction was also performed using Amano PS, CalB raw extract, and lyophilized CalB (referred to as CalB powder) (Figure 3). The enzymes achieved maximum conversions of $50 \%$ after $24 \mathrm{~h}$ for CalB powder and $48 \mathrm{~h}$ for Amano PS. CalB raw extract (non- immobilized) achieved a conversion of only $29 \%$ in the same time periods. The CalB raw extract established no equilibrium, probably due to the inactivation of the enzyme. This was confirmed by a renewed increase in conversion after fresh enzyme was added (see the Supporting Information S3). In addition, a high water content, 35.7\%, was measured for CalB raw extract. In the presence of water, acetaldehyde is generated as a byproduct (Scheme 3), which often leads to enzyme deactivation over time due to Schiff base formation with lysine resi-

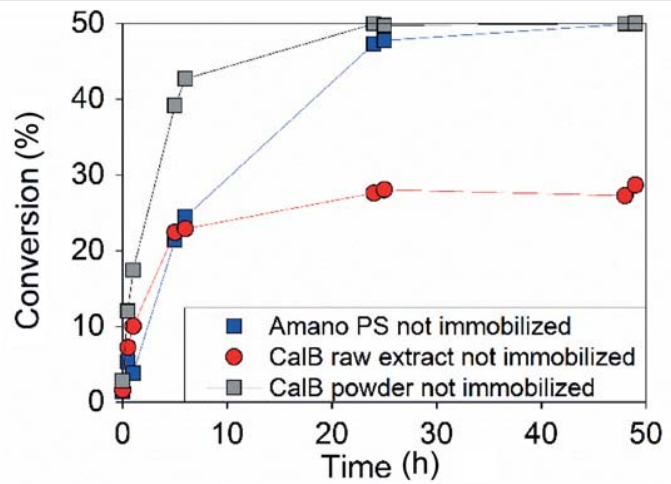

Figure 3 Comparison of various lipases applied for kinetic racemic resolution. Conditions: $20 \mathrm{~mL}$ dodecane, $10 \mathrm{mM}$ rac-1-phenylethanol, 100 $\mathrm{mM}$ vinyl acetate, $26.4 \mathrm{mg}$ Amano PS / $200 \mu \mathrm{L}$ CalB raw extract / 75.4 mg CalB powder non-immobilized, $40^{\circ} \mathrm{C}, 49 \mathrm{~h}$, measured once. 
dues. ${ }^{25}$ Nevertheless, CalB was not excluded, because deactivation due to acetaldehyde can be prevented by immobilizing the enzyme. ${ }^{26}$

Interestingly, each of the three enzymes showed a different behavior after immobilization in hydrogel (Figure 4). Initially, the conversions of CalB powder and CalB raw extract showed equal increases, whereas the conversion of Amano PS increased more slowly. Using this immobilization technique, CalB raw extract achieved the best result of $44 \%$ conversion, followed by CalB powder with $40 \%$ conversion and Amano PS with 37\%. Conversion with the hydrogel-immobilized CalB raw extract was 15\% higher than that of the non-immobilized form, probably due to the previously mentioned positive effect of imidazolium cation on CalB activity. The CalB powder suffered inactivation by the immobilization procedure and, therefore, the conversion percentage was lower than that for the non-immobilized enzyme. Amano PS also exhibited decreased activity after immobilization.

Unfortunately, none of the three hydrogel-immobilized lipases achieved the maximum conversion of 50\%. Kazlauskas et al. reported that, even under anhydrous reaction conditions, the hydrolysis of the vinyl acetate was three times faster than the desired acetylation of 1-phenylethanol. ${ }^{27}$ Using hydrogels as an immobilization matrix, the amount of water increased in the reaction system. Consequently, the amount of vinyl acetate available for the transesterification decreased rapidly.

To improve the conversion, the hydrogels were dried under vacuum $\left(10^{-3}\right.$ mbar) for either 6 or $13 \mathrm{~h}$, rather than being air dried for one day. As shown in the Supporting Information S4, the water content in the hydrogel decreased from $18.6 \%$ to $5.1 \%$ after 6 h drying time and from $16.6 \%$ to $2.0 \%$ after 13 h drying time. As Figure 5 shows, using vacuum-dried hydrogels caused a loss of enzyme activity. The conversion decreased from $44 \%$ for air-dried hydrogels to $43 \%$ after $6 \mathrm{~h}$ of drying and to 33\% after $13 \mathrm{~h}$ drying. Generally, the water in hydrogels is categorized as either free or bound. ${ }^{28}$ Lower amounts of free water might affect the enzyme folding, resulting in reduced conversion. In addition, diffusion is limited by the pore size of the hydrogel and the reduced solvent content, leading to lower reaction rates. Future work will concentrate on small hydrogel particles in a fixed-bed reactor or as a thin film in a continuously operated plug-flow reactor. Doing this can engineer the reaction to overcome mass-transport limitations. This will allow use of different concentration-time and concentration-place behaviors of the batch-reactor, continuously operated plugflow reactor, or stirred-tank reactor.

Apart from the influence of water, acetic acid can be produced in both side reactions (Scheme 3 ). The resulting acidification of the system may result in $\mathrm{pH}$ values beyond the preferred optimum or may even damage the enzyme. In general, the hydrogel itself can buffer the system at a $\mathrm{pH}$ of about 7.0 based on its composition. However, to exclude

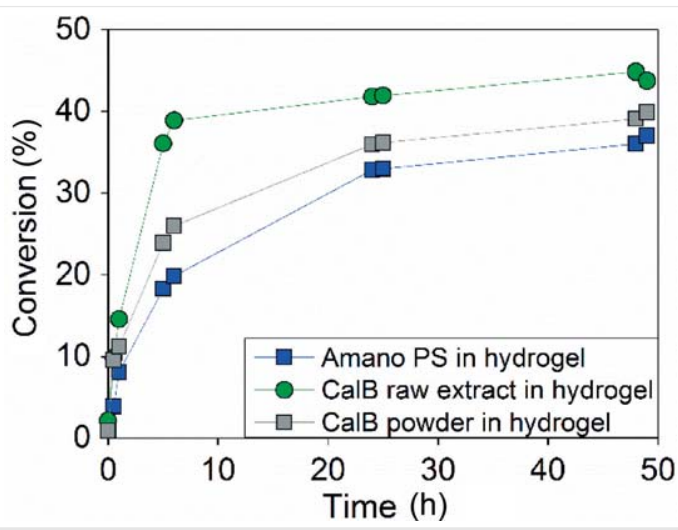

Figure 4 Comparison of various hydrogel-immobilized lipases applied for kinetic racemic resolution. Conditions: $20 \mathrm{~mL}$ dodecane, $10 \mathrm{mM}$ rac1-phenylethanol, $100 \mathrm{mM}$ vinyl acetate, $26.4 \mathrm{mg}$ Amano PS / $200 \mu \mathrm{L}$ CalB raw extract $/ 75.4 \mathrm{mg}$ CalB powder immobilized in hydrogel, $40^{\circ} \mathrm{C}$, $49 \mathrm{~h}$, measured once.

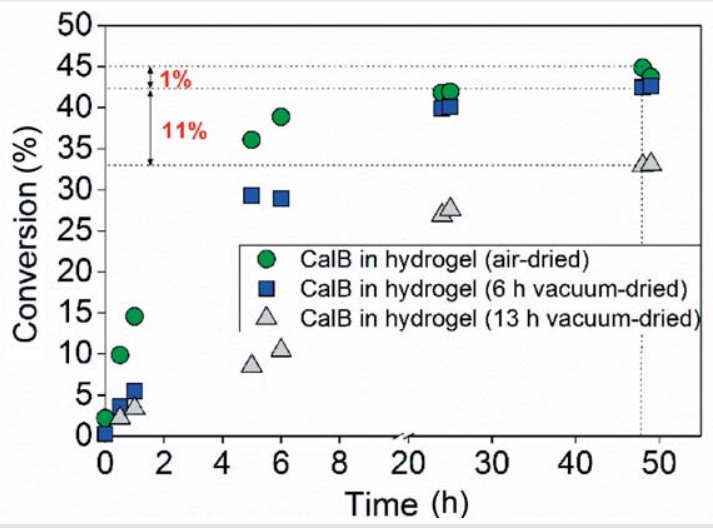

Figure 5 Influence of various drying methods on the conversion. Conditions: $20 \mathrm{~mL}$ dodecane, $10 \mathrm{mM}$ rac-1-phenylethanol, $100 \mathrm{mM}$ vinyl acetate, $200 \mu \mathrm{L}$ CalB raw extract immobilized in hydrogel, $40^{\circ} \mathrm{C}, 49 \mathrm{~h}$, measured once.

this possibility, additional phosphate buffer was embedded during the synthesis procedure. As the Supporting Information S5 shows, the results were very similar, and no further improvement was obtained.
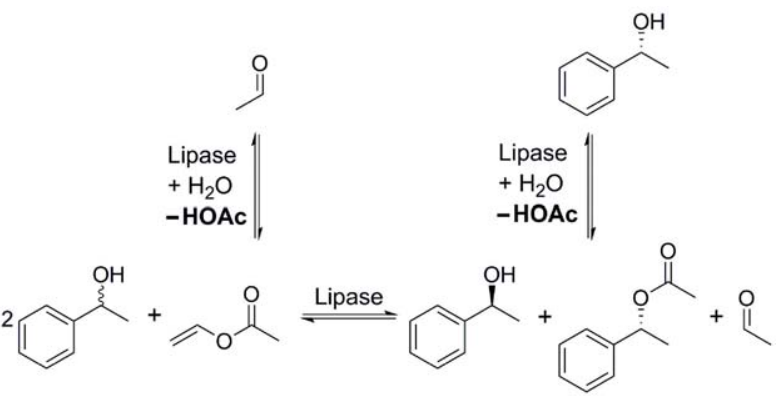

Scheme 3 Undesired side reactions of kinetic racemic resolution 
The hydrogel-immobilization method presented was compared to Novozyme 435 and Lipozyme RM IM as commercially available immobilisates (Figure 6). Both showed higher activities compared to the immobilized enzyme in the hydrogel. Conversion rates of $49 \%$ for Novozyme 435 and $47 \%$ for Lipozyme RM IM were achieved after $5 \mathrm{~h}$ reaction time. In the same period, the hydrogel-immobilized CalB achieved only $36 \%$ conversion. A possible reason for the longer reaction time is the limitation on diffusion imposed by the polymeric structure, which is quite different from the other immobilized forms. Novozyme 435 is the lipase B from Candida Antarctica that has been immobilized by adsorption on a microporous resin ${ }^{29}$ and Lipozyme RM IM, a lipase from Rhizomucor miehei, is adsorbed onto an anion exchange resin. ${ }^{29}$ In both cases, lipases were immobilized by adsorption on a resin surface, whereas CalB raw extract is embedded in the polymeric hydrogel framework. These primary experiments show that the immobilization matrix and the procedure itself influences the performance of the reaction. Diffusion and mass-transport behavior are under investigation in our laboratories. In addition, adsorption of the desired product inside the polymer structure cannot be excluded at this time. The dependency of the crosslinker to IL ratio on the transport behavior is also being investigated.

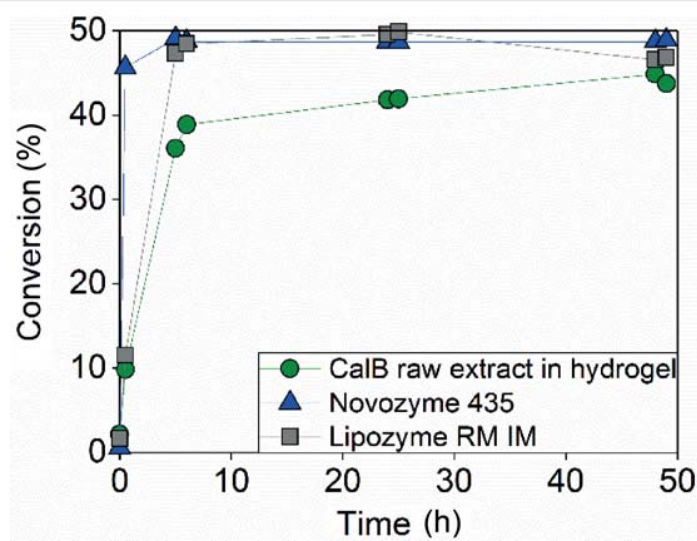

Figure 6 Comparison to commonly used immobilization methods. Reaction conditions: $20 \mathrm{~mL}$ dodecane, $10 \mathrm{mM}$ rac-1-phenylethanol, 100 $\mathrm{mM}$ vinyl acetate, $200 \mu \mathrm{L}$ CalB immobilized in hydrogel or $0.4 \mathrm{~g}$ Novozyme 435 or $0.4 \mathrm{~g}$ Lipozyme RM IM, $40{ }^{\circ} \mathrm{C}, 49 \mathrm{~h}$, measured once.

One great disadvantage of immobilization by adsorption is the high amount of enzyme leaching; whereas an economically viable process requires complete recovery of the enzyme. For this reason, we examined the leaching behavior of hydrogels containing enzyme amounts of between $200 \mu \mathrm{L}$ and $400 \mu \mathrm{L}$ at $25^{\circ} \mathrm{C}$ and $40^{\circ} \mathrm{C}$. Fortunately, no enzyme leaching was found (see experimental section) and even higher amounts of CalB raw extract can be immobilized in hydrogel without enzyme leaching. Another benefit, observed during the immobilization process, was that the hydrogels became more stable and less adhesive when higher amounts of CalB raw extract were embedded, although this did not influence the velocity of the reaction. Furthermore, leaching was analyzed using gel electrophoresis, and no enzyme leaching was detected for either swollen or shrunken hydrogels.

The lipase B from Candida antarctica has proven to be non-specific towards triglycerides but very enantio- and stereospecific. In the reaction performed, the CalB preferentially catalyzed the transformation of $(R)$-1-phenylethanol. Therefore, the $(R)$-enantiomer of the product should be achieved with a high enantiomeric excess (ee) and a maximum conversion of $50 \%$. Over time, the $(S)$-enantiomer of the educt should accumulate in the reaction mixture. Figure 7 shows the results for conversion and $e e$ at $40{ }^{\circ} \mathrm{C}$ (the conversion and $e e$ at $25^{\circ} \mathrm{C}$ are shown in the Supporting Information S6).

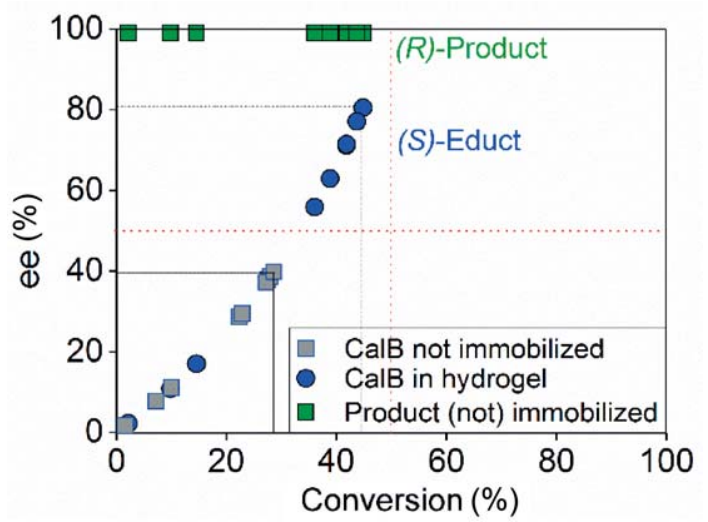

Figure 7 Conversion and enantiomeric excess of $(R)$-product and $(S)$ educt at $40{ }^{\circ} \mathrm{C}$. Reaction conditions: $20 \mathrm{~mL}$ dodecane, $10 \mathrm{mM}$ rac-1phenylethanol, $100 \mathrm{mM}$ vinyl acetate, $200 \mu \mathrm{L}$ CalB raw extract non-immobilized or immobilized in hydrogel, $40^{\circ} \mathrm{C}, 49 \mathrm{~h}$, measured once.

As expected, the $(R)$-product was steadily formed with an $e e$ of $>99 \%$. This means that only the $(R)$-1-phenylethanol was converted by the CalB. This was confirmed by the accumulation of the $(S)$-educt in the reaction mixture, which also resulted in its increased ee. This trend was observed with both the non-immobilized and the hydrogel-immobilized CalB raw extract. In the case of the non-immobilized CalB, the (S)-1-phenylethanol developed an ee of $39.8 \%$ in the reaction mixture after $49 \mathrm{~h}$ at $40{ }^{\circ} \mathrm{C}$. Using the hydrogelimmobilized enzyme, the conversion was $15 \%$ higher and included higher enrichment of the (S)-educt $(80.5 \%$ ee $)$.

One of the key criteria of commercial immobilized enzymes is reusability for a large number of reaction cycles combined with nearly no loss of activity. The recycling potential of hydrogel-immobilized CalB raw extract was tested over $8 \mathrm{~h}$ at $40{ }^{\circ} \mathrm{C}$ (Figure 8 , blue bar). After the first run, conversion decreased from $26 \%$ to $18 \%$. After six cycles, the conversion remained constant at $10 \%$. In comparison, when the procedure was repeated at $25^{\circ} \mathrm{C}$ (Figure 8 , red bar), the 
conversion was generally higher, decreasing by only by $0.6 \%$ after the first run. Typically, the highest loss of activity should be seen between the first and second runs due to the leaching of unfixed enzyme. In this case, after the second run, the conversion decreased to $22.6 \%$ and after the tenth run to $8.7 \%$. Furthermore, recycling experiments were performed over a reaction time of $48 \mathrm{~h}$ at $25{ }^{\circ} \mathrm{C}$ using various dried hydrogels.

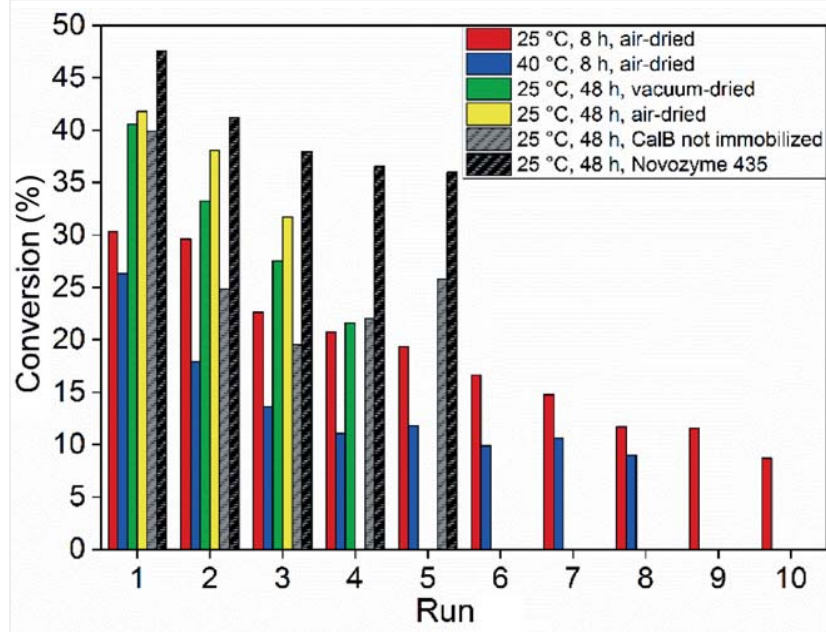

Figure 8 Results for recycling experiments for air-dried and vacuumdried hydrogels over a period of $8 \mathrm{~h}$ and $48 \mathrm{~h}$. As a reference, non-immobilized CalB and Novozyme 435 were used. Reaction conditions: 20 $\mathrm{mL}$ dodecane, $10 \mathrm{mM}$ rac-1-phenylethanol, $100 \mathrm{mM}$ vinyl acetate, 200 $\mu \mathrm{L}$ CalB raw extract immobilized in hydrogel (air-dried/vacuum-dried), 8 h / 48 h, measured once.

The results were compared using non-immobilized CalB and commercially available Novozyme 435, which is composed of CalB immobilized on a microporous acrylic resin and is a biocatalyst much used in industry. The application of vacuum-dried hydrogels led to higher losses of activity of $6 \%$ from cycle to cycle. The best results were achieved with air-dried hydrogels at $25{ }^{\circ} \mathrm{C}$ with conversions of $42 \%$ after the first cycle and $32 \%$ after the third cycle. The activity of non-immobilized CalB decreased significantly from $40 \%$ after the first cycle to $25 \%$ after the second. In addition, the hydrogels (immobilized CalB) showed better performance than the non-immobilized CalB. In comparison, Novozyme 435 showed good performance, having conversions of $48 \%$ after the first cycle and 36\% after the fifth. However, it also experienced a significant decrease in conversion from batch to batch. In spite of the relatively good performance and the many advantages that Novozyme 435 offers, there are two general concerns related to this enzyme. Firstly, the high cost, which can be attributed at least partly to the immobilization-support material, and secondly, the high amount of enzyme leaching. Novozyme 435 has been shown to suffer from physical desorption or leaching of CalB during various reactions. ${ }^{30}$ The presence of water enhances leaching from the surface of Novozyme $435 .^{31}$ In some applications, in- cluding for medical materials or pharmaceuticals, protein contamination of products is unacceptable. Although the hydrogels studied are not as good as the Novozyme 435, they offer several advantages under various conditions. The present study presents another mode of attachment of the enzyme that prevented the catalyst from leaching. No leaching of enzymes was found in organic or aqueous solvents. This new immobilization matrix could be very interesting in unconventional media including supercritical $\mathrm{CO}_{2}$ or ILs, in which Novozyme 435 has sometimes shown lower activity. For example, Hobbs et al. found that CalB CLEA had higher activity than Novozyme 435 in the kinetic resolution of 1-phenylethanol by acylation with vinyl acetate in supercritical $\mathrm{CO}_{2}{ }^{32}$ In addition, decreased activity has been found in Novozyme 435 in the kinetic resolution of 1-phenyl ethanol and 1-phenylethylamine in various ILs. ${ }^{33}$ Furthermore, the choice of enzyme immobilisates is strongly dependent on the reactor configuration used (e.g., stirred tank, fixed bed, fluidized bed) and the mode of downstream processing. Using simple methodology, hydrogels can be prepared in various shapes, including small particles, that have different surface-area-to-volume ratios for fixed-bed reactors, or thin films for continuously operated plug-flow reactors. This method combines immobilization and purification, and the enzyme does not need to be highly purified.

This study found that immobilization of CalB in po$\operatorname{ly}(\mathrm{VEImBr})$ is possible and achieves good results in nonpolar solvents. To enable assessment of the potential of PILbased hydrogels for catalyst immobilization and identification of areas that need further research, Figure 9 presents a SWOT analysis. The greatest strengths of this method are the simplified downstream processing and the complete lack of catalyst leaching during the reaction time. This will lead to increased productivity; whereas decoupling the residence time of biocatalyst and reactants will at the same time reduce the product-specific catalyst consumption.

However, the largest threat is the novelty of this method. Possible interactions between enzymes and enzyme support differ with the enzyme applied and the reaction used and must be investigated for each reaction. In the example presented herein, the immobilization matrix led to positive interactions between the enzyme and enzyme support and the immobilized enzyme showed higher activity than the non-immobilized enzyme.

Although the present study did not achieve a maximum conversion of $50 \%$, this was not due to the immobilization matrix. The study used a highly water-dependent enzymatic reaction. Undesirable side reactions were observed in the presence of water. Future work will investigate the influence of water content and water activity. Apart from that, hydrogel-immobilized CalB could also be applied in a less water-sensitive reaction, or this immobilization technique could be applied to other enzymes for a wider range of applications. 


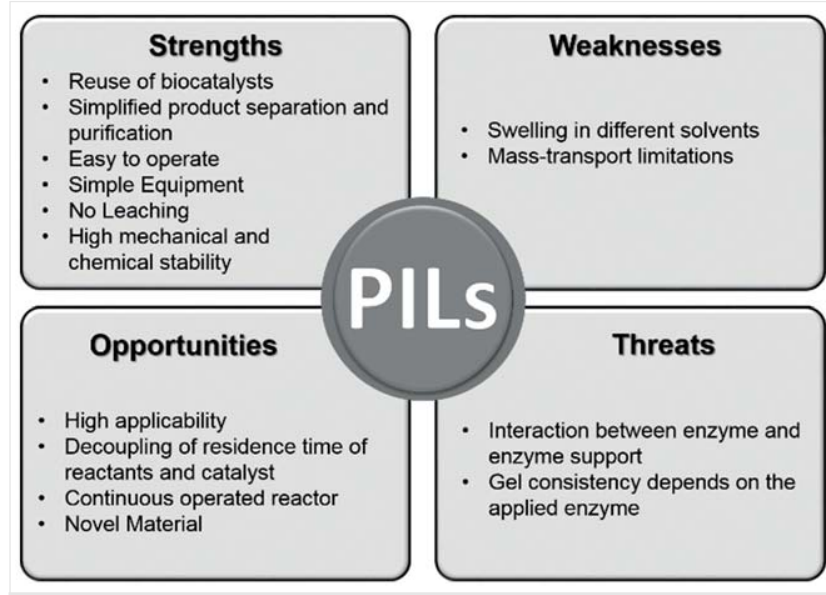

Figure 9 SWOT analysis for the potential of PIL-based hydrogels as a novel immobilization method for biocatalysts

Future work will concentrate on diffusion behavior, mass-transport limitations, and the influence of varying the crosslinker-to-IL ratio. In addition, this technique offers many advantages for practical applications, including easy removal of the catalyst, and novel reactor concepts due to its enhanced mechanical and chemical stability.

In summary, the present study demonstrates the combination of enzymes with PIL-based hydrogels as an immobilization technique for easy reusability and separation of enzymes. This immobilization method increases the enzyme activity of CalB raw extract in comparison to the non-immobilized enzyme. The desired product is synthesized with a high enantiomeric excess and the enzyme is easily reused for several steps due to the high mechanical and chemical stability of the PILs.

All chemicals and solvents were purchased from Sigma-Aldrich, Alfa Aesar, Carl Roth GmbH \& Co KG., and TCI and used as received. Lipase B from Candida antarctica was obtained as a purified raw extract from C. Lecta (Germany). Lipase B Candida Antarctica recombinant from Aspergillus oryzae and Amano Lipase PS from Burkholderia cepacia were obtained from Sigma-Aldrich.

\section{Enzyme Encapsulation in PIL-Based Hydrogels}

1-Vinyl-3-ethylimidazolium bromide (VEImBr) was synthesized according to the reported procedure. ${ }^{34}$ The IL monomer (VEImBr, $0.3 \mathrm{~g}$ ) was dissolved in deionized water $(432 \mu \mathrm{L})$ and Rotiphorese Gel B (232 $\mu \mathrm{L}, N, N^{\prime}$-methylenebisacrylamide) was added. In the case of enzyme embedding, the required amount of water was reduced by the added enzyme volume. When a solid enzyme was used, no correction was made. The enzyme solution was added to the IL monomer solution. Polymerization was initiated with fresh ammonium persulfate $(30 \mu \mathrm{L}$, $10 \%, \mathrm{w} / \mathrm{w})$ and TEMED $(6 \mu \mathrm{L})$, and the resulting solution was thoroughly mixed for $10 \mathrm{~s}$. The gelation process was complete, forming transparent gels after 10 to $120 \mathrm{~min}$. The hydrogels were air-dried for one day, unless otherwise noted. To achieve equal activities, the following enzyme amounts were used: $200 \mu \mathrm{L}$ of CalB raw extract, 75.39 mg of CalB powder, and $26.34 \mathrm{mg}$ of Amano PS. However, due to the relatively high masses for the CalB powder, the calculated enzyme amount was split and immobilized into two hydrogel charges.

\section{Enzyme Assay: Lipases}

Hydrolysis of $p$-nitrophenyl esters to $p$-nitrophenol was used. The reaction was carried out using $10 \mathrm{mM}$ of $p$-nitrophenyl acetate in DMSO and $100 \mathrm{mM}$ of phosphate buffer at $\mathrm{pH}$ 7.5. The various enzyme dilutions were prepared in buffer in the following way: Lipase B from Candida antarctica $=1: 100$, Lipase B Candida Antarctica recombinant from Aspergillus oryzae $=2 \mathrm{mg} / \mathrm{mL}$ or Amano Lipase PS from Burkholderia cepacia $=1 \mathrm{mg} / \mathrm{mL}$. The yellow phenolate ion that formed was photometrically measured three times over a period of $60 \mathrm{~s}$ at $401 \mathrm{~nm}$ and $30^{\circ} \mathrm{C}$.

Immobilized enzymes were handled differently. A defined amount of the immobilized enzyme ( $10 \mathrm{mg}$ of Novozyme 435 or $20 \mathrm{mg}$ of Lipozyme RM IM) was stirred in a $50 \mathrm{~mL}$ batch reactor using cuvette concentrations. Samples of $1000 \mu \mathrm{L}$ were taken at defined intervals, filtered, and the extinctions determined.

\section{Kinetic Resolution of $(\boldsymbol{R}, \boldsymbol{S})$-1-Phenylethanol with Vinyl Acetate}

For each reaction, rac-1-phenylethanol $(24.2 \mu \mathrm{L}, 10 \mathrm{mM})$, vinyl acetate $(185.2 \mu \mathrm{L}, 100 \mathrm{mM}$ ) and CalB (non-immobilized or immobilized in hydrogel) were added to solvent $(20 \mathrm{~mL})$ in a glass vial. The reaction mixture was shaken at a fixed temperature in a Thermomixer at $500 \mathrm{rpm}$. Samples of $400 \mu \mathrm{L}$ were taken at intervals and analyzed by gas chromatography.

\section{Gas Chromatography Conditions}

The analytical investigations were performed by gas chromatography using a cyclodextrin column CP-ChiraSil-Dex CB (25 m $\times 0.25 \mathrm{~mm}$ $0.25 \mu \mathrm{m})$. Both temperature and solvent screening tests were analyzed under isothermic conditions of $120^{\circ} \mathrm{C}$ for $10 \mathrm{~min}$. Experiments performed in dodecane were treated differently: the initial temperature was $60^{\circ} \mathrm{C}$, which was followed by a heating rate of $25^{\circ} \mathrm{C} \cdot \mathrm{min}^{-1}$ to $135^{\circ} \mathrm{C}$ and $2{ }^{\circ} \mathrm{C} \cdot \mathrm{min}^{-1}$ to $160^{\circ} \mathrm{C}$. The final temperature was held for 1 min. Conversions and enantiomeric excesses were calculated by integrating the respective peak areas.

\section{Determination of Enzyme Leaching}

The leaching behavior was investigated first by determining the conversion and then by gel electrophoresis. Reactions were performed in dodecane at $25^{\circ} \mathrm{C}, 40{ }^{\circ} \mathrm{C}$, and $55^{\circ} \mathrm{C}$ over a period of $5 \mathrm{~h}$. Samples of $700 \mu \mathrm{L}$ were taken at $0 \mathrm{~min}, 15 \mathrm{~min}, 30 \mathrm{~min}, 1 \mathrm{~h}, 3 \mathrm{~h}$ and $5 \mathrm{~h}$. After centrifuging, $300 \mu \mathrm{L}$ was taken from the supernatant and analyzed by GC; whereas the remaining volume was mixed at $40^{\circ} \mathrm{C}$ for 2 more hours, after which samples were taken and analyzed. If there was any enzyme in the mixture, an increase in conversion should be seen after 2 more hours. Gel electrophoresis (SDS-PAGE) as a reliable method for protein detection was chosen to confirm the previous results. Two different approaches were adopted. In both cases $200 \mu \mathrm{L}$ of CalB raw extract immobilized in hydrogel was applied. Firstly, the kinetic resolution was performed as usual at $40{ }^{\circ} \mathrm{C}$, using dodecane as a solvent. Samples of $400 \mu \mathrm{L}$ were taken at $1 \mathrm{~h}, 3 \mathrm{~h}$, and $5 \mathrm{~h}$ without centrifuging. For gel electrophoresis, the dodecane was evaporated and the residue was redissolved in phosphate buffer $(200 \mu \mathrm{L}, \mathrm{pH} 7.5,100 \mathrm{mM})$. Secondly, the hydrogel was shaken in phosphate buffer $(20 \mathrm{~mL}$, $\mathrm{pH} 7.5,100 \mathrm{mM}$ ) for $1 \mathrm{~h}$ at $25^{\circ} \mathrm{C}$. After $0 \mathrm{~min}, 10 \mathrm{~min}, 30 \mathrm{~min}$, and 60 min, samples of $400 \mu \mathrm{L}$ were taken without subsequent centrifugation. In addition, an enzyme dilution was prepared (CalB raw extract/water $=1: 2$ ). 


\section{Determination of Water Activity}

The water activity measurements were carried out according to the reported procedure. ${ }^{35} 15 \mathrm{~mL}$ of each sample (enzyme solutions, reaction solutions and organic solvents) was prepared and determined. The humidity sensor was a Greisinger TFS 0100E, connected to a Greisinger GMH 3330 hygrometer. Water activity is simply calculated as the ratio of measured vapor pressure to the saturation value of pure water at the same temperature.

\section{Funding Information}

This work was financially supported by the DFG (grant KR 2491/12-1) and the Federal Ministry of Education and Research (BMBF, 'Ionische Flüssigkeiten in der Enzymkatalyse', grant 031A123). In addition, this work has been carried out within the framework of the SMART BIOTECS alliance between Technische Universität Braunschweig and the Leibniz Universität Hannover. This initiative is supported by the Ministry of Economy and Culture (MWK) of Lower Saxony, Germany.

\section{Supporting Information}

Supporting information for this article is available online at https://doi.org/10.1055/s-0037-1610144.

\section{References}

(1) (a) Es, I.; Vieira, J. D. G.; Amaral, A. C. Appl. Microbiol. Biotechnol. 2015, 99, 2065. (b) DiCosimo, R.; McAuliffe, J.; Poulose, A. J.; Bohlmann, G. Chem. Soc. Rev. 2013, 42, 6437. (c) Liese, A.; Hilterhaus, L. Chem. Soc. Rev. 2013, 42, 6236. (d) Messing, R. Immobilized Enzymes for Industrial Reactors; Elsevier: Amsterdam, 2012.

(2) (a) Bornscheuer, U. T. Angew. Chem. Int. Ed. 2003, 42, 3336. (b) Schmid, A.; Dordick, J. S.; Hauer, B.; Kiener, A.; Wubbolts, M.; Witholt, B. Nature 2001, 409, 258. (c) Anastas, P.; Eghbali, N. Chem. Soc. Rev. 2010, 39, 301. (d) Anastas, P. T.; Kirchhoff, M. M. Acc. Chem. Res. 2002, 35, 686.

(3) Sheldon, R. A. Adv. Synth. Catal. 2007, 349, 1289.

(4) Sheldon, R. A. Chem. Soc. Rev. 2012, 41, 1437.

(5) (a) Datta, S.; Christena, L. R.; Rajaram, Y. R. S. 3 Biotech 2013, 3, 1-9. (b) Garcia Galan, C.; Berenguer Murcia, Á.; Fernandez Lafuente, R.; Rodrigues, R. C. Adv. Synth. Catal. 2011, 353, 2885. (c) Mateo, C.; Palomo, J. M.; Fernandez-Lorente, G.; Guisan, J. M.; Fernandez-Lafuente, R. Enzyme Microb. Technol. 2007, 40, 1451.

(6) Sheldon, R. A.; van Pelt, S. Chem. Soc. Rev. 2013, 42, 6223.

(7) Kartal, F.; Janssen, M. H. A.; Hollmann, F.; Sheldon, R. A.; Kılınc, A. J. Mol. Catal. B: Enzym. 2011, 71, 85.

(8) Sheldon, R. A.; Schoevaart, R.; van Langen, L. M. Biocatal. Biotransform. 2005, 23, 141.

(9) (a) Nemzer, L. R.; Schwartz, A.; Epstein, A. J. Macromolecules 2010, 43, 4324. (b) Gonzalez-Saiz, J. M.; Pizarro, C. Eur. Polym. J. 2001, 37, 435 .

(10) (a) Ahuja, T.; Mir, I. A.; Kumar, D. Biomaterials 2007, 28, 791. (b) Ghosh, S.; Chaganti, S. R.; Prakasham, R. S. J. Mol. Catal. B: Enzym. 2012, 74, 132. (c) Taqieddin, E.; Amiji, M. Biomaterials 2004, 25, 1937.
(11) (a) Yuan, J.; Mecerreyes, D.; Antonietti, M. Prog. Polym. Sci. 2013, 38, 1009. (b) Yuan, J.; Antonietti, M. Polymer 2011, 52, 1469. (c) Yoshizawa, M.; Ogihara, W.; Ohno, H. Polym. Adv. Technol. 2002, 13, 589. (d) Claus, J.; Sommer, F. O.; Kragl, U. Solid State Ionics 2018, 314, 119.

(12) (a) Green, O.; Grubjesic, S.; Lee, S.; Firestone, M. A. Polym. Rev. 2009, 49, 339. (b) Lu, J.; Yan, F.; Texter, J. Prog. Polym. Sci. 2009, 34, 431. (c) Mecerreyes, D. Prog. Polym. Sci. 2011, 36, 1629.

(13) Nakashima, K.; Kamiya, N.; Koda, D.; Maruyama, T.; Goto, M. Org. Biomol. Chem. 2009, 7, 2353.

(14) (a) Moniruzzaman, M.; Kamiya, N.; Goto, M. Langmuir 2008, 25, 977. (b) Moniruzzaman, M.; Kamiya, N.; Nakashima, K.; Goto, M. ChemPhysChem 2008, 9, 689. (c) Moniruzzaman, M.; Kamiya, N.; Nakashima, K.; Goto, M. Green Chem. 2008, 10, 497.

(15) Moniruzzaman, M.; Ino, K.; Kamiya, N.; Goto, M. Org. Biomol. Chem. 2012, 10, 7707.

(16) López, M. S.-P.; Mecerreyes, D.; Lopez-Cabarcos, E.; López-Ruiz, B. Biosens. Bioelectron. 2006, 21, 2320.

(17) Zhang, Q.; Wu, S.; Zhang, L.; Lu, J.; Verproot, F.; Liu, Y.; Xing, Z.; Li, J.; Song, X.-M. Biosens. Bioelectron. 2011, 26, 2632.

(18) Großeheilmann, J.; Bandomir, J.; Kragl, U. Chem. Eur. J. 2015, 21, 18957.

(19) Bandomir, J.; Schulz, A.; Taguchi, S.; Schmitt, L.; Ohno, H.; Sternberg, K.; Schmitz, K. P.; Kragl, U. Macromol. Chem. Phys. 2014, 215, 716 .

(20) Kazlauskas, R. J.; Weissfloch, A. N. E.; Rappaport, A. T.; Cuccia, L. A. J. Org. Chem. 1991, 56, 2656.

(21) Faber, K. Biotransformations in Organic Chemistry 1992.

(22) Schöfer, S. H.; Kaftzik, N.; Wasserscheid, P.; Kragl, U. Chem. Commun. 2001, 425.

(23) Kim, H. S.; Eom, D.; Koo, Y.-M.; Yingling, Y. G. Phys. Chem. Chem. Phys. 2016, 18, 22062.

(24) (a) Kim, K.-W.; Song, B.; Choi, M.-Y.; Kim, M.-J. Org. Lett. 2001, 3, 1507. (b) Lau, R. M.; Sorgedrager, M. J.; Carrea, G.; van Rantwijk, F.; Secundo, F.; Sheldon, R. A. Green Chem. 2004, 6, 483. (c) Lozano, P.; de Diego, T.; Carrie, D.; Vaultier, M.; Iborra, J. L. Biotechnol. Lett. 2001, 23, 1529. (d) Madeira Lau, R.; van Rantwijk, F.; Seddon, K. R.; Sheldon, R. A. Org. Lett. 2000, 2, 4189.

(25) Franken, B.; Eggert, T.; Jaeger, K. E.; Pohl, M. BMC Biochem. 2011, $12,10$.

(26) Gandhi, N. N.; Patil, N. S.; Sawant, S. B.; Joshi, J. B.; Wangikar, P. P.; Mukesh, D. Catal. Rev. 2000, 42, 439.

(27) Weber, H. K.; Weber, H.; Kazlauskas, R. J. Tetrahedron: Asymmetry 1999, 10, 2635.

(28) Hoffman, A. S. Adv. Drug Delivery Rev. 2012, 64, 18.

(29) Hernández-Martín, E.; Otero, C. Bioresour. Technol. 2008, 99, 277.

(30) Chen, B.; Hu, J.; Miller, E. M.; Xie, W.; Cai, M.; Gross, R. A. Biomacromolecules 2008, 9, 463.

(31) Sheldon, R. A. Biochem. Soc. Trans. 2007, 35, 1583.

(32) Hobbs, H. R.; Kondor, B.; Stephenson, P.; Sheldon, R. A.; Thomas, N. R.; Poliakoff, M. Green Chem. 2006, 8, 816.

(33) Toral, A. R.; Antonia, P.; Hernández, F. J.; Janssen, M. H. A.; Schoevaart, R.; van Rantwijk, F.; Sheldon, R. A. Enzyme Microb. Technol. 2007, 40, 1095.

(34) Marcilla, R.; Alberto Blazquez, J.; Rodriguez, J.; Pomposo, J. A.; Mecerreyes, D. J. Polym. Sci., Part A: Polym. Chem. 2004, 42, 208.

(35) Cassells, J. M.; Halling, P. J. Enzyme Microb. Technol. 1988, 10, 486. 